CLINICAL STUDY

\title{
Total and high molecular weight adiponectin are elevated in patients with Laron syndrome despite marked obesity
}

\author{
Hannah Kanety $^{1}$, Rina Hemi ${ }^{1}$, Shira Ginsberg ${ }^{2}$, Clara Pariente ${ }^{1}$, Eleanor Yissachar ${ }^{1,3}$, Ehud Barhod $^{1,3}$, \\ Tohru Funahashi ${ }^{4}$ and Zvi Laron ${ }^{2}$ \\ ${ }^{1}$ Institute of Endocrinology, Chaim Sheba Medical Center, Tel-Hashomer 52621, Israel, ${ }^{2}$ Endocrinology and Diabetes Research Unit, Schneider Childrens \\ Medical Center of Israel, Petah Tikva, Israel; both affiliated to the Sackler Faculty of Medicine, Tel Aviv University, Tel Aviv, Israel, ${ }^{3}$ The Mina and Everard \\ Goodman Faculty of Life Sciences, Bar-Ilan University, Ramat-Gan, Israel and ${ }^{4}$ Department of Metabolic Medicine, Graduate School of Medicine, \\ Osaka University, Osaka, Japan
}

(Correspondence should be addressed to H Kanety; Email: hkanety@sheba.health.gov.il)

\begin{abstract}
Objective: Patients with Laron syndrome (LS; primary GH insensitivity) caused by molecular defects of the GH receptor gene, are characterized by dwarfism, profound obesity, and hyperlipidemia. The aim of the current study was to evaluate adiponectin levels in LS, as obesity is known to be associated with low adiponectin.

Design and methods: We studied nine untreated LS adult patients ( 5 males, 4 females) and six girls with LS receiving once-daily treatment by IGF1. Total and high molecular weight (HMW) adiponectin levels, adiponectin multimers distribution, and metabolic indices were analyzed in serum samples obtained during several years of follow-up.

Results: Adiponectin levels in the severely obese adult LS patients (percent body fat; females $61.0 \pm 2.5 \%$, males $40.6 \pm 8.1 \%$ ) were two- to three-fold higher than those reported for subjects of corresponding age, gender and degree of adiposity. Total adiponectin was significantly higher in females compared with males $(21.4 \pm 3.5 \mathrm{vs} 10.2 \pm 4.6 \mu \mathrm{g} / \mathrm{ml}, P<0.001)$. The elevated adiponectin in LS subjects was associated with an increased abundance of the HMW isoform, and positively correlated with body fat percentage $(r=0.65, P=0.017)$ and leptin $(r=0.65, P=0.012)$. There was no correlation between adiponectin levels (total and HMW) and the degree of insulin resistance in LS subjects or their blood lipids levels. Adiponectin was also high in young girls with LS $(22.9 \pm 7.4 \mu \mathrm{g} / \mathrm{ml})$ and did not change during long-term IGF1 replacement therapy.

Conclusion: Adiponectin hypersecretion in LS, despite profound obesity, suggests that GH activity may negatively impact adiponectin secretion from adipocytes.
\end{abstract}

European Journal of Endocrinology $161837-844$

\section{Introduction}

Laron syndrome (LS; primary GH insensitivity or resistance, OMIM \#262500) is a rare autosomal recessively inherited disease found mainly in consanguineous families originating from Mediterranean, Mideastern or south Asian regions or in their descendants (1-5). It is caused by deletions (6) or mutations in the GH receptor gene $(2-4,7,8)$, resulting in the absence of GH activity, and congenital insulin-like growth factor-1 (IGF1) deficiency (2). The only treatment is IGF1 replacement therapy (9).

One of the phenotypical characteristics of LS, in addition to dwarfism, is profound obesity (10-12), noticed already in early infancy (13), which does not decrease during long-term IGF1 treatment (14). Concomitantly with a marked increase in subcutaneous and visceral fat $(2,12)$, the majority of patients with LS progressively develop signs of the metabolic syndrome like hyperlipidemia (11) and nonalcoholic fatty liver disease (15).

Adiponectin is the most abundant hormone produced by the adipose tissue of humans and rodents and has insulin-sensitizing and anti-atherogenic properties (reviewed in $(16,17)$ ). It circulates in three distinct multimers: trimers, hexamers and larger multimers of 12-18 subunits (high molecular weight, HMW); the latter appears to be the most active form of the hormone $(16,17)$. Adiponectin levels differ with age, gender and obesity. At birth, adiponectin levels are extremely high (18-20) and fall off gradually until puberty $(19,21)$. During pubertal development an additional progressive decline in adiponectin levels occurs mainly in boys, which leads to lower adiponectin levels compared 
with girls. This decline is strongly associated with androgen levels and accounts for the gender differences seen in adults (21).

Unlike most other adipocytokines that increase with the excess of body fat mass, adiponectin levels are markedly reduced in obesity, in both adults and children (21-25) and negatively correlate with body mass index (BMI) and percent body fat. The decrease in adiponectin in obesity is probably due to reduced concentrations of the HMW adiponectin isoform (26-28). It was therefore of interest to determine the serum levels of adiponectin and the HMW adiponectin multimer in both untreated adult patients with LS and in children with LS undergoing IGF1 treatment, all very obese. This paper presents the unexpected results of this investigation.

\section{Subjects and methods}

\section{Subjects}

All the patients with LS were followed and treated at the Endocrinology and Diabetes Research Unit, Schneider Children's Medical Center of Israel. Nine untreated adult LS patients aged 29-53 years, ( 5 males, 4 females) and 6 girls (5-16 years) receiving once daily treatment by IGF1 (120-180 $\mu \mathrm{g} / \mathrm{kg}$ s.c.; Fujisawa, Osaka, Japan) were investigated. The diagnosis of LS in these patients was ascertained using the IGF1 generation test (2) and by molecular analysis of the $\mathrm{GH}$ receptor gene (5). The pertinent clinical data of the patients, arranged by gender and age, are shown in Tables 1 and 2. Of note, due to underdevelopment of the muscular and skeletal systems in the patients with LS (2), the BMI does not accurately reflect the degree of obesity in these subjects $(12,14)$. Therefore, percentage of body fat estimated by dual-energy by X-ray absortiometry (DEXA) and not
BMI was used in this study as a measure of adiposity. In addition, no ideal control group to match the dwarfism and severe obesity of LS patients was available; hence, our data was compared to existing data in the literature for morbidly obese subjects of normal stature (Table 3). This comparison employed only data obtained with the same analytical methodology used in the current study to measure adiponectin and leptin concentrations. The study was approved by the Hospital Ethical Committee and the patients or their parents signed an informed consent form.

\section{Methods}

Hormonal assays Blood samples were collected from all participants during their long-term follow-up. Blood was drawn after an overnight (12-14 h) fast, serum samples were separated and analyzed for general blood chemistry and insulin at the same day. For adiponectin and leptin measurements, samples were stored at $-30{ }^{\circ} \mathrm{C}$ and analyzed together. Total adiponectin and leptin were determined by RIA (Linco, Millipore, St Charles, MO, USA; 18, 29) and the HMW-adiponectin was measured by HMW-adiponectin ELISA kit (Otsuka Pharmaceutical Co. Ltd, Tokyo, Japan) (30). The interassay coefficient of variations (CV) for leptin, adiponectin, and HMW-adiponectin were $<6.2$, $<9.3$, and $<10 \%$ respectively. Intra-assay $\mathrm{CV}$ for each of the three were $<8.3,<6.5$, and $<10 \%$ respectively. The distribution of adiponectin multimers in serum samples was analyzed under nonreducing and nondenaturing conditions as described previously (29, 31). Abundance of adiponectin multimers was determined by densitometry. Insulin was determined by a solid-phase two-site chemiluminescent immunometric assay (Immulite 2000, Siemens Medical Solutions Diagnostics, Los Angeles, CA, USA) and

Table 1 Anthropometric and hormonal parameters of untreated adults and insulin-like growth factor-1 (IGF1) treated pediatric patients with Laron syndrome during long-term follow-up.

\begin{tabular}{lccc}
\hline & \multicolumn{2}{c}{ Adults } & Children \\
\cline { 2 - 3 } & Males $n=5, x=9$ & Females $n=4, x=6$ & Females $n=6, x=26$ \\
\hline Age (years) & $39.4 \pm 8.2(29-51)$ & $48.8 \pm 5.1(43-53)$ & $10.4 \pm 3.7(5-16.6)$ \\
Height $(\mathrm{m})$ & $1.3 \pm 0.1(1.16-1.40)$ & $1.25 \pm 0.1(1.12-1.36)$ & $1.15 \pm 0.15(0.89-1.41)$ \\
Weight $(\mathrm{kg})$ & $46.4 \pm 13.4(27.9-66)$ & $47.5 \pm 9.3(44-60)$ & $33.8 \pm 18.1(12.3-70.1)$ \\
Body fat $(\%)$ by DEXA & $40.6 \pm 8.1(31.6-49.7)$ & $61.0 \pm 2.5^{\star}(58.5-64.5)$ & $46.5 \pm 13.5^{\dagger}(25.0-62.8)$ \\
Adiponectin $(\mu \mathrm{g} / \mathrm{ml})$ & $10.2 \pm 4.6(6.5-21.1)$ & $21.4 \pm 3.5^{\star}(15.9-25.1)$ & $22.9 \pm 7.4(15-32.5)$ \\
HMW adiponectin $(\mu \mathrm{g} / \mathrm{ml})$ & $5.3 \pm 3.4(1.7-12.5)$ & $15.4 \pm 2.3^{*}(13.0-17.6)$ & $19.2 \pm 4.9(13.7-26.8)$ \\
Leptin $(\mathrm{ng} / \mathrm{ml})$ & $11.3 \pm 4.9(6.1-19.7)$ & $27.9 \pm 2.7^{\star}(25-31.8)$ & $27.3 \pm 5.3(9.2-63.4)$ \\
Leptin/adiponectin ratio $\times 10^{-3}$ & $1.2 \pm 0.7(0.29-2.52)$ & $1.4 \pm 0.2(1.11-1.57)$ & $1.2 \pm 0.7(0.63-3.11)$ \\
Insulin $(\mu \mathrm{lU} / \mathrm{ml})$ & $3.8 \pm 1.4(2-5.2)$ & $5.0 \pm 3.8(2-10.1)$ & $5.1 \pm 4.2(2-11.9)$ \\
Glucose $(\mathrm{mg} / \mathrm{dl})$ & $84.2 \pm 12.2(74-99)$ & $82.3 \pm 5.7(74-87)$ & $80.1 \pm 7.4(69-87)$ \\
HOMA-IR & $0.77 \pm 0.31(0.49-1.23)$ & $1.02 \pm 0.65(0.42-2.16)$ & $1.12 \pm 0.97(0.34-2.82)$ \\
Total cholesterol $(\mathrm{mg} / \mathrm{dl})$ & $146.8 \pm 28.9(195-248)$ & $232.3 \pm 25.2(218-270)$ & $170.5 \pm 22.8^{\dagger}(129-205)$ \\
Triglycerides $(\mathrm{mg} / \mathrm{dl})$ & $115.8 \pm 49.6(48-157)$ & $135 \pm 13.9(117-151)$ & $77.4 \pm 25.5^{\dagger}(50-101)$ \\
\hline
\end{tabular}

Data are means \pm s.D., ranges in parentheses. $n$, number of patients in the indicated group; $x$, number of samples in the indicated group, obtained from patients at different time points during their long-term follow-up. ${ }^{\star} P<0.05$ females versus male LS patients. ${ }^{\dagger} P<0.05$ girls versus female LS patients. Some of the LS adults with hyperlipidemia received statin therapy. 
Table 2 Serum adiponectin and leptin in girls with Laron syndrome during long-term insulin-like growth factor-1 (IGF1) treatment ${ }^{\mathrm{a}}$.

\begin{tabular}{|c|c|c|c|c|c|c|}
\hline Patient no. & Age (years) & Ht (m) & Wt (kg) & $\%$ Body fat & $\begin{array}{l}\text { Adiponectin } \\
(\mu \mathrm{g} / \mathrm{ml})\end{array}$ & $\begin{array}{l}\text { Leptin } \\
\text { (ng/ml) }\end{array}$ \\
\hline \multirow[t]{5}{*}{1} & $\begin{array}{l}5 \\
5.3\end{array}$ & 0.96 & 17 & 47 & $\begin{array}{l}25.7 \\
28.1\end{array}$ & $\begin{array}{l}5.4 \\
13\end{array}$ \\
\hline & 6 & 0.98 & 19 & & 22.2 & 14 \\
\hline & 6.2 & & & & 25 & 18 \\
\hline & 6.5 & & & & 19.4 & 13.3 \\
\hline & 7 & 1.03 & 18.6 & & 29.8 & 11.8 \\
\hline \multirow[t]{2}{*}{2} & 6 & 0.89 & 12.3 & 25 & 24.8 & 16.8 \\
\hline & 6.3 & & & & 15 & 17.9 \\
\hline \multirow[t]{6}{*}{3} & 9 & 1.1 & 25.2 & 49.1 & 17.0 & 12.2 \\
\hline & 9.6 & & & & 23.8 & 20 \\
\hline & 10 & 1.12 & 27.6 & & 16.4 & 21.9 \\
\hline & 10.4 & & & & 18.5 & 33.1 \\
\hline & 10.8 & 1.13 & 26.6 & & 18.9 & 14.4 \\
\hline & 11 & 1.14 & 27.8 & & 19.9 & 21.4 \\
\hline \multirow[t]{2}{*}{4} & 9.5 & 1.16 & 30 & & 20.3 & 17.5 \\
\hline & 10 & 1.19 & 30 & & 23.1 & 19.1 \\
\hline \multirow[t]{6}{*}{5} & 12 & 1.07 & 25 & 48.7 & 27.7 & 56.1 \\
\hline & 12.3 & & & & 25.9 & 42.1 \\
\hline & 13.2 & 1.14 & 30 & & 24.9 & 47.8 \\
\hline & 13.6 & & & & 20.8 & 49.8 \\
\hline & 13.9 & & & & 31.5 & 40.5 \\
\hline & 14.3 & 1.19 & 33 & & 32.5 & 63.4 \\
\hline \multirow[t]{4}{*}{6} & 15 & 1.38 & 64 & 62.8 & 15.2 & 47.2 \\
\hline & 15.5 & 1.39 & 72 & & 26.1 & 35.5 \\
\hline & 16 & 1.41 & 70.1 & & 19.4 & 33.9 \\
\hline & 16.6 & 1.41 & 70.1 & & 22.9 & 23.5 \\
\hline
\end{tabular}

aAll samples were obtained during IGF1 therapy (9), with one exception (first sample of patient 2).

blood chemistry by a Hitachi autoanalyzer. Insulin resistance was estimated by the homeostasis model assessment insulin resistance index (HOMA-IR; 32) and HOMA index was calculated according to the formula: glucose $(\mathrm{mmol} / \mathrm{l}) \times$ insulin $(\mu \mathrm{U} / \mathrm{ml}) / 22.5$.

Body composition Body fat was determined using DEXA (Model DPX-IQ 8565-A, Lunar Radiation Corp., Madison, WI, USA).

\section{Data analysis}

Data are presented as means \pm s.D. Statistical analyses were performed using Student's t-test for two-group comparisons. Spearman's correlation analysis was used to examine bivariate relationships. Significance tests were two-tailed, and $P$ values $<0.05$ were considered as statistically significant. Calculations were performed using SPSS 11.0 (SPSS Inc., Chicago, IL, USA).

\section{Results}

\section{Anthropometric and hormonal data of LS patients}

Forty-one sera from 15 patients with LS ( 9 adults and 6 IGF1-treated children), obtained during long-term

Table 3 Comparison of mean serum adiponectin and leptin levels in Laron syndrome (LS) patients and subjects with a similar degree of obesity.

\begin{tabular}{lcccll}
\hline Group & Age & \% Body fat (by DEXA) & Adiponectin $(\mu \mathrm{g} / \mathrm{ml})$ & Leptin $(\mathrm{ng} / \mathrm{ml})$ & Reference \\
\hline LS females & $48.8 \pm 5.1$ & $61.0 \pm 2.5$ & $21.4 \pm 3.5$ & $27.9 \pm 2.7$ & This study \\
Obese females & $42.0 \pm 3.0$ & $50.5 \pm 3.6$ & $5.0 \pm 2.2$ & $31.3 \pm 12$ & $(36)$ \\
Obese females & $37.7 \pm 9.6$ & $47.8 \pm 5.1$ & $11.4 \pm 4.3$ & NA & $(37)$ \\
LS males & $39.4 \pm 8.2$ & $40.6 \pm 8.1$ & $10.2 \pm 4.6$ & $11.3 \pm 4.9$ & This study \\
Obese males & $25.0 \pm 4.1$ & $41.1 \pm 8.3$ & $6.0 \pm 4.1$ & NA & $(38)$ \\
LS girls & $10.4 \pm 3.7$ & $46.5 \pm 13.5$ & $22.9 \pm 7.4$ & $27.3 \pm 5.3$ & This study \\
Obese girls & $10.8 \pm 3.8$ & $41.4 \pm 4.8$ & $11.9 \pm 5.2$ & $30.2 \pm 16.8$ & $(42)$ \\
Obese girls & $11.2 \pm 3.6$ & $41.2 \pm 5.2$ & $12.0 \pm 5.1$ & $26.8 \pm 13.5$ & $(40)$ \\
Obese girls & $13.1 \pm 1.8$ & $41.4 \pm 4.8$ & $9.6 \pm 3.0$ & NA & $(41)$ \\
Obese girls & $11.1 \pm 0.2$ & $40.6 \pm 0.6$ & $10.0 \pm 0.4$ & $31.1 \pm 1.5$ & $(43)$ \\
\hline
\end{tabular}

NA, not available.

This comparison employed only data obtained with the same analytical methodology used in the current study to measure adiponectin and leptin concentrations (RIA, Linco). 
follow-up were analyzed. Anthropometric data of the patients as well as mean levels of total and HMW-adiponectin, leptin, circulating lipids, insulin, glucose, and HOMA-IR are shown in Table 1. As shown, all LS patients are very short and very obese (Table 1) with body fat above normal and higher than what we usually measure in obese subjects (33). Adult female subjects have significantly higher $\mathrm{BF} \%$ than males $(P<0.01)$. Percent body fat of our adult LS female subjects was $59-65 \%$ compared to $36-51 \%$ in age matched healthy controls (33) and a body fat of $32-50 \%$ in the adult LS males compared to $12-37 \%$ in healthy male subjects of the same age range (33).

\section{Adiponectin and leptin levels in adult untreated LS patients}

Despite their profound obesity, the adult LS patients have both high total adiponectin and high leptin levels (Table 1, Fig. 1A and B), with both adipokines (Fig. 1A and B) being significantly higher in the female compared with the male LS patients (adiponectin; $21.4 \pm 3.5$ vs $10.2 \pm 4.6 \mu \mathrm{g} / \mathrm{ml}, P<0.001$ and leptin; $27.9 \pm 2.5$ vs $11.3 \pm 4.9 \mathrm{ng} / \mathrm{ml}, P<0.001)$.

Unlike the well established negative correlation of total adiponectin with the degree of obesity and with leptin levels found in the general population $(22,24,25)$, adiponectin levels in the adult LS subjects were positively correlated with the percent of body fat $(r=0.65$, $P=0.017)$ and leptin levels $(r=0.65, P=0.012)$. No correlation was observed between adiponectin levels and a variety of metabolic parameters, including blood lipids, HOMA-IR, and insulin levels.

To further examine adiponectin characteristics in LS patients, we compared the distribution of the distinct adiponectin multimers in the sera of LS females and healthy lean females (29; Fig. 2). While previous studies have demonstrated that the HMW adiponectin isoform is markedly reduced in obese subjects compared with lean counterparts $(27,28)$, in the severely obese LS females the abundance of the HMW isoform was
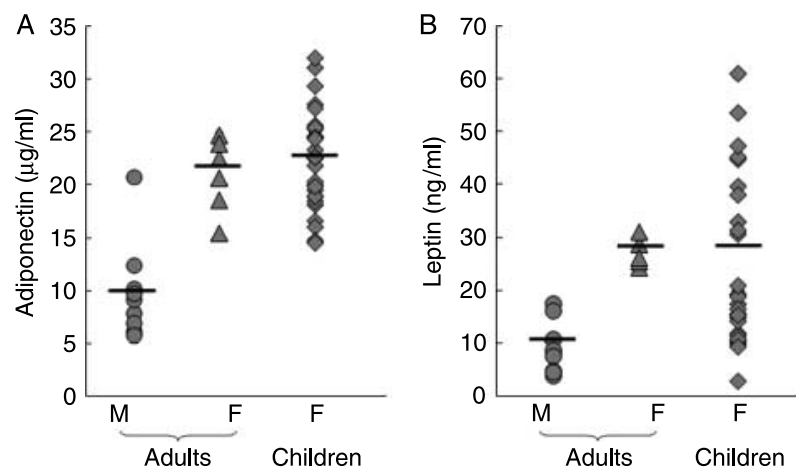

Figure 1 Individual adiponectin levels (A) and leptin levels (B) in LS patients. $M$, male; $F$, female; mean value in each group is indicated by a line. threefold higher $(P=0.01)$ than in the lean controls (Fig. 2A) and accordingly, the ratio of HMW/total adiponectin was significantly higher in the LS females $(P<0.001)$ than in the lean controls (Fig. 2B). No significant differences were found in the abundance of the hexamer $(P=0.38)$ and trimer $(P=0.2)$ isoforms in sera of LS and lean control women. In addition, circulating HMW-adiponectin and total adiponectin levels in adult LS patients (Table 1) were highly correlated with each other $(r=0.92, P<0.001)$. Similar to our findings for total adiponectin, the HMW adiponectin levels were significantly higher in female compared with male LS patients $(15.4 \pm 2.3$ vs $5.3 \pm 3.4 \mu \mathrm{g} / \mathrm{ml} P<0.001)$ and positively correlated with the percent of body fat $(r=0.64, P=0.05)$ and leptin levels $(r=0.69, P=0.03)$, but not with any of the metabolic indices.

\section{Adiponectin and leptin in IGF1 treated LS girls}

We studied 6 girls with LS, aged 5-15 years, during 3-28 months of IGF1 therapy. The longitudinal changes in adiponectin and leptin levels during the follow-up period, along with changes in their height and weight, are illustrated in Table 2. With one exception (patient 2, Table 2) for whom we had a pretreatment blood sample, adiponectin and leptin levels measurements were performed in blood samples obtained during IGF1 therapy. Unlike obese girls of similar age and degree of adiposity (23), the pretreatment adiponectin levels in patient 2 were high $(24.8 \mu \mathrm{g} / \mathrm{ml})$ and decreased after 3 months of IGF1 therapy $(15 \mu \mathrm{g} / \mathrm{ml})$. Adiponectin levels in the other five IGF1 treated girls were also very high, despite being markedly obese (Tables 1 and 2, Fig. 1A). As shown in Table 2, despite fluctuations adiponectin levels did not change significantly during the longterm IGF1 therapy; however, we cannot exclude the possibility that at the beginning of therapy, the adiponectin levels were higher, as seen in patient 2 . In accordance with their profound obesity, leptin concentrations in the LS girls were very high (Tables 1 and 2 , Fig. 1B). It is noteworthy that leptin levels were higher in the older than the younger girls, most likely due to their higher degree of obesity, whereas adiponectin levels were not considerably different between the age groups. Adiponectin levels of adolescent girls with LS (patients 3-6, Table 2) were significantly elevated compared with levels we measured in another study (34) for lean $(P<0.05)$ and obese $(P<0.001)$ girls of similar age.

Similar to our observations in adults, there was a statistical positive correlation between adiponectin and leptin $(r=0.55, P=0.02)$ in the adolescent girls with LS. We could not evaluate the association between adiponectin or leptin and the degree of obesity, due to the small number of body fat composition measurements in the LS girls. 

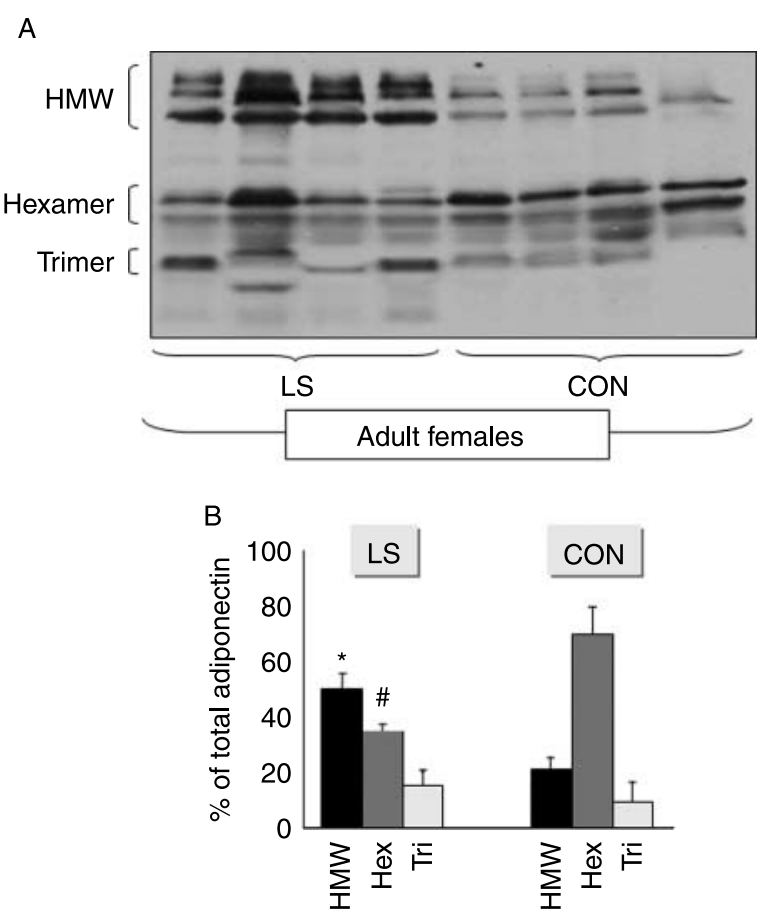

Figure 2 Distribution of adiponectin multimeric forms in serum of females with LS and healthy lean females. Adiponectin multimer distribution was analyzed in serum samples of four LS females (LS) and four healthy lean females (BMI, $20.2 \pm 2.1 \mathrm{~kg} / \mathrm{m}^{2}$; CON). $0.5 \mu$ of serum were subjected to $5-15 \%$ SDS-PAGE under nonreducing and nonheat-denaturing conditions. Adiponectin was detected by a specific antibody (Chemicon). (A) Three different molecular weight groups were detected in all samples: High molecular weight (HMW), hexamer (Hex), and trimer (Tri). The abundance of specific adiponectin multimers was quantified by densitometry of the relevant bands. (B) The relative proportion of each multimer to total adiponectin (\% of total adiponectin) was obtained by dividing band density of the specific multimer by total density in each lane. ${ }^{\star} P<0.001 \mathrm{HMW} /$ Total adiponectin ratio - LS versus CON.

${ }^{\#} P<0.001 \mathrm{Hex} /$ Total adiponectin ratio - LS versus CON.

\section{Discussion}

LS is an interesting model for studying adiponectin physiology. The key observation in the current study was that patients with LS, who are GH insensitive and IGF1 deficient, have elevated adiponectin levels, despite being severely obese. The elevated adiponectin levels were accounted for largely by the HMW adiponectin isoform. Adiponectin concentrations of both female and male adult LS patients were considerably higher (two- to three-fold), compared to reported data for obese subjects of similar age, gender and with an equivalent degree of adiposity (Table 3), whereas leptin levels were comparable $(24,25,35-38)$. In addition, when adiponectin levels in LS females were normalized for individual body fat percent, they were higher $(0.36 \pm 0.06)$, compared with reported data for obese healthy women (0.17$0.21 ; 35,39)$. Similar to adults, adiponectin levels in the girls with LS were significantly higher compared with healthy girls of similar age and degree of adiposity
(Table 3; 40-43). Contrary to the healthy population, total and HMW adiponectin in LS patients positively correlated with the degree of adiposity and leptin levels.

Our findings of high adiponectin in patients with GH insensitivity are supported by similar observations in the GH receptor knockout mice $(44,45)$. Furthermore, $\mathrm{GH}$ suppressed adiponectin secretion in in vitro cultured human adipose tissue (45), and GH treatment of prepubertal short stature children resulted in decreased serum adiponectin levels (46). Collectively these findings raise the intriguing possibility that $\mathrm{GH}$ activity may negatively affect adiponectin production or secretion from adipocytes; however, the mechanism underlying this process is as yet unclear. It may be attributed to loss of a direct suppression of adiponectin synthesis or secretion by $\mathrm{GH}$, as the $\mathrm{GH}$ receptor is expressed in adipocytes, or alternatively to repression by IGF1 or IGF binding protein-3 (IGFBP-3), known to be deficient in LS $(2,47)$. Indeed, suppressive effects of GH and IGFBP-3 on adipocyte secretion of adiponectin are supported by recent in vitro and ex vivo studies $(45,48)$. Unlike GH and IGFBP-3, in vitro studies did not support an inhibitory effect of IGF1 on adiponectin secretion (49). Our observation that the elevated adiponectin levels in LS children did not change significantly and consistently during prolonged IGF1 treatment may support this notion, but the lack of sufficient observations before initiation of IGF1 treatment prevents a definite conclusion. It is noteworthy that in addition to LS, high adiponectin levels were documented in patients with Prader-Willi syndrome (PWS), who have diminished GH secretion (50) as well as in fetuses at late gestation or newborns (20), who have significantly lower numbers of $\mathrm{GH}$ receptors compared with the postnatal state (51). These observations lend further support to the hypothesis that $\mathrm{GH}$ activity is an important modulator of adiponectin levels.

The biosynthesis of adiponectin multimers is a complex process involving extensive post-translational modifications, which are necessary for the intracellular assembly and stabilization of its HMW multimers (28). The secretion of these multimers from adipocytes is tightly controlled by a pair of molecular chaperones in the endoplasmic reticulum, ERp44 and Ero1-L $\alpha$, known to be regulated by the metabolic state of the cell and PPAR $\gamma$ agonists, and to display sexual dimorphism (52). Our findings that GH insensitivity is associated with high circulating adiponectin levels, combined with a shift towards the HMW forms, raises an intriguing possibility that $\mathrm{GH}$ activity may affect adiponectin secretion by modulating the levels of these chaperons. Further research will be required to address this hypothesis.

GH plays a critical role in the regulation of body composition and both children and adults with GH deficiency or GH insensitivity present with increased adiposity and decreased lean body mass (2-4). Accumulating data obtained from magnetic resonance 
imaging (MRI) measurements of abdominal subcutaneous and visceral fat depots in healthy obese adults and children support the notion that excessive visceral rather than subcutaneous adiposity is associated with decreased production and circulating levels of adiponectin $(53,54)$. Contrary to healthy obese subjects, MRI studies in patients with PWS, who have diminished GH secretion, revealed an unusual situation in which their increased obesity is associated with a relative reduction in visceral adiposity (55). Based on these findings it was proposed (50) that the elevated adiponectin in PWS subjects is a reflection of their proportionately lesser amount of visceral adiposity. As obesity in LS affects both the trunk and the limbs $(2,12,14)$, with a great proportion of their fat being localized subcutaneously, in addition to around the visceral organs $(2,12)$, it is appealing to examine whether alterations in body fat depots distribution underlie the dissociation between hyperadiponectinemia and adiposity in LS patients. MRI studies, to determine the ratio of visceral to subcutaneous adiposity in adults and children with LS, will be necessary to test this hypothesis.

Interestingly, despite their profound obesity, HOMAIR was abnormal (2.2) in only one adult LS patient, in marked contrast to morbidly obese subjects who display a high degree of insulin resistance with HOMA-IR values of 5-9 $(56,57)$. A similar dissociation between profound obesity and insulin resistance was observed in the $\mathrm{GH}$ receptor $\mathrm{KO}$ mice $(44,45)$. Using a mouse model with chronic GH deficiency it was recently demonstrated that $\mathrm{GH}$ insensitivity is associated with decreased p85 $\alpha$ expression and improved insulin receptor substrate (IRS)-1-associated PI3 kinase activity in the adipose tissue, leading to enhanced insulin sensitivity in conjunction with increased lipid deposition and enhanced adiponectin secretion (58). This provides an explanation for the insulin hypersensitivity and associated obesity and hyperadiponectinemia of the GH-insensitive mice (58), as well as for the lower than expected insulin resistance in LS patients in relation to their profound obesity.

One limitation of our study lies in the relatively small number of subjects in each LS group, as LS is a rare disease with a very small number of affected subjects worldwide; in addition, the lack of an obese control group limits the interpretation of the results of the present study.

In conclusion, adiponectin levels in patients with LS and GH insensitivity are elevated, despite their marked obesity. Our findings highlight the complex regulation of adiponectin secretion from adipocytes and underline the negative role of $\mathrm{GH}$ function on adiponectin secretion. In addition to the contribution of our novel findings in the understanding of adiponectin regulation, other clinical implications can be envisaged. As high adiponectin is associated with a lower risk for cancer development $(59,60)$, it is possible that the high adiponectin levels in LS patients contribute to the mechanism which protects patients with LS from malignancies (61).

\section{Declaration of interest}

The authors declare that there is no conflict of interest that could be perceived as prejudicing the impartiality of the research reported.

\section{Funding}

This research did not receive any specific grant from any funding agency in the public, commercial or not-for-profit sector.

\section{Acknowledgements}

Presented in part at the 89th Annual Meeting of The Endocrine Society, June 2007, Toronto, Canada.

\section{References}

1 Laron Z, Pertzelan A \& Mannheimer S. Genetic pituitary dwarfism with high serum concentation of growth hormone - a new inborn error of metabolism? Israel Journal of Medical Sciences 19662 $152-155$.

2 Laron Z. Laron syndrome (primary growth hormone resistance or insensitivity): the personal experience 1958-2003. Journal of Clinical Endocrinology and Metabolism 200489 1031-1044.

3 Rosenfeld RG, Rosenbloom AL \& Guevara-Aguirre J. Growth hormone $(\mathrm{GH})$ insensitivity due to primary $\mathrm{GH}$ receptor deficiency. Endocrine Reviews 199415 369-390.

4 Savage MO, Attie KM, David A, Metherell LA, Clark AJ \& CamachoHubner C. Endocrine assessment, molecular characterization and treatment of growth hormone insensitivity disorders. Nature Clinical Practice. Endocrinology \& Metabolism 20062 395-407.

5 Shevah $\mathrm{O} \&$ Laron Z. Genetic analysis of the pedigrees and molecular defects of the GH-receptor gene in the Israeli cohort of patients with Laron syndrome. Pediatric Endocrinology Reviews 20063 489-497.

6 Godowski PJ, Leung DW, Meacham LR, Galgani JP, Hellmiss R, Keret R, Rotwein PS, Parks JS, Laron Z \& Wood WI. Characterization of the human growth hormone receptor gene and demonstration of a partial gene deletion in two patients with Laron-type dwarfism. PNAS 198986 8083-8087.

7 Amselem S, Duquesnoy P, Duriez B, Dastot F, Sobrier ML, Valleix S \& Goossens M. Spectrum of growth hormone receptor mutations and associated haplotypes in Laron syndrome. Human Molecular Genetics 19932 355-359.

8 Shevah O, Rubinstein M \& Laron Z. Molecular defects of the growth hormone receptor gene, including a new mutation, in Laron syndrome patients in Israel: relationship between defects and ethnic groups. Israel Medical Association Journal 2004 6 630-633.

9 Laron Z. Insulin-like growth factor-I treatment of children with Laron syndrome (primary growth hormone insensitivity). Pediatric Endocrinology Reviews 20085 766-771.

10 Laron Z, Pertzelan A \& Karp M. Pituitary dwarfism with high serum levels of growth hormone. Israel Journal of Medical Sciences $19684883-894$.

11 Laron Z \& Klinger B. Body fat in Laron syndrome patients: effect of insulin-like growth factor I treatment. Hormone Research 1993 $4016-22$.

12 Laron Z, Ginsberg S, Lilos P, Arbiv M \& Vaisman N. Body composition in untreated adult patients with Laron syndrome (primary GH insensitivity). Clinical Endocrinology $2006 \mathbf{6 5}$ 114-117. 
13 Laron Z, Klinger B, Grunebaum M, Feingold M \& Tunnessen WW. Picture of the month. Laron-type dwarfism. American Journal of Diseases and Children 1991145 473-474.

14 Laron Z, Ginsberg S, Lilos P, Arbiv M \& Vaisman N. Long-term IGF-I treatment of children with Laron syndrome increases adiposity. Growth Hormone \& IGF Research 200616 61-64.

15 Laron Z, Ginsberg S \& Webb M. Nonalcoholic fatty liver in patients with Laron syndrome and GH gene deletion - preliminary report. Growth Hormone \& IGF Research 200818 434-438.

16 Kadowaki $\mathrm{T} \&$ Yamauchi T. Adiponectin and adiponectin receptors. Endocrine Reviews 200526 439-451.

17 Trujillo ME \& Scherer PE. Adipose tissue-derived factors: impact on health and disease. Endocrine Reviews 200627 762-778.

18 Sivan E, Mazaki-Tovi S, Pariente C, Efraty Y, Schiff E, Hemi R \& Kanety $\mathrm{H}$. Adiponectin in human cord blood: relation to fetal birth weight and gender. Journal of Clinical Endocrinology and Metabolism 200388 5656-5660.

19 Iniguez G, Soto N, Avila A, Salazar T, Ong K, Dunger D \& Mericq V. Adiponectin levels in the first two years of life in a prospective cohort: relations with weight gain, leptin levels and insulin sensitivity. Journal of Clinical Endocrinology and Metabolism 2004 89 5500-5503.

20 Tsai PJ, Yu CH, Hsu SP, Lee YH, Chiou CH, Hsu YW, Ho SC \& $\mathrm{Chu} \mathrm{CH}$. Cord plasma concentrations of adiponectin and leptin in healthy term neonates: positive correlation with birthweight and neonatal adiposity. Clinical Endocrinology 2004 61 88-93.

21 Bottner A, Kratzsch J, Muller G, Kapellen TM, Bluher S, Keller E, Bluher M \& Kiess W. Gender differences of adiponectin levels develop during the progression of puberty and are related to serum androgen levels. Journal of Clinical Endocrinology and Metabolism $2004894053-4061$.

22 Arita Y, Kihara S, Ouchi N, Takahashi M, Maeda K, Miyagawa J, Hotta K, Shimomura I, Nakamura T, Miyaoka K, Kuriyama H, Nishida M, Yamashita S, Okubo K, Matsubara K, Muraguchi M, Ohmoto Y, Funahashi T \& Matsuzawa Y. Paradoxical decrease of an adipose-specific protein, adiponectin, in obesity. Biochemical and Biophysical Research Communications 1999257 79-83.

23 Stefan N, Bunt JC, Salbe AD, Funahashi T, Matsuzawa Y \& Tataranni PA. Plasma adiponectin concentrations in children: relationships with obesity and insulinemia. Journal of Clinical Endocrinology and Metabolism 200287 4652-4656.

24 Kern PA, Di Gregorio GB, Lu T, Rassouli N \& Ranganathan G. Adiponectin expression from human adipose tissue: relation to obesity, insulin resistance, and tumor necrosis factor-alpha expression. Diabetes 200352 1779-1785.

25 Ryan AS, Berman DM, Nicklas BJ, Sinha M, Gingerich RL, Meneilly GS, Egan JM \& Elahi D. Plasma adiponectin and leptin levels, body composition, and glucose utilization in adult women with wide ranges of age and obesity. Diabetes Care 200326 2383-2388.

26 Kaser S, Tatarczyk T, Stadlmayr A, Ciardi C, Ress C, Tschoner A, Sandhofer A, Paulweber B, Ebenbichler CF \& Patsch JR. Effect of obesity and insulin sensitivity on adiponectin isoform distribution. European Journal of Clinical Investigation 200838 827-834.

27 Schraw T, Wang ZV, Halberg N, Hawkins M \& Scherer PE. Plasma adiponectin complexes have distinct biochemical characteristics. Endocrinology 2008149 2270-2282.

28 Wang Y, Lam KS, Yau MH \& Xu A. Post-translational modifications of adiponectin: mechanisms and functional implications. Biochemical Journal 2008 409 623-633.

29 Modan-Moses D, Stein D, Pariente C, Yaroslavsky A, Ram A, Faigin M, Loewenthal R, Yissachar E, Hemi R \& Kanety H. Modulation of adiponectin and leptin during refeeding of female anorexia nervosa patients. Journal of Clinical Endocrinology and Metabolism 200792 1843-1847.

30 Komura N, Kihara S, Sonoda M, Kumada M, Fujita K, Hiuge A, Okada T, Nakagawa Y, Tamba S, Kuroda Y, Hayashi N, Sumitsuji S, Kawamoto T, Matsumoto S, Ouchi N, Arita Y, Okamoto Y,
Shimomura I, Funahashi T \& Matsuzawa Y. Clinical significance of high-molecular weight form of adiponectin in male patients with coronary artery disease. Circulation Journal 2008 72 23-28.

31 Waki H, Yamauchi T, Kamon J, Ito Y, Uchida S, Kita S, Hara K, Hada Y, Vasseur F, Froguel P, Kimura S, Nagai R \& Kadowaki T. Impaired multimerization of human adiponectin mutants associated with diabetes. Molecular structure and multimer formation of adiponectin. Journal of Biological Chemistry $2003 \mathbf{2 7 8}$ $40352-40363$.

32 Matthews DR, Hosker JP, Rudenski AS, Naylor BA, Treacher DF \& Turner RC. Homeostasis model assessment: insulin resistance and beta-cell function from fasting plasma glucose and insulin concentrations in man. Diabetologia 198528 412-419.

33 Ginsberg S, Laron Z, Arbiv Bed M \& Vaisman N. The obesity of patients with Laron syndrome is not associated with excessive nutritional intake. Obesity Research \& Clinical Practice 20093 3-8.

34 Pinhas-Hamiel O, Singer S, Pilpel N, Koren I, Boyko V, Hemi R, Pariente C \& Kanety H. Adiponectin levels in adolescent girls with polycystic ovary syndrome. Clinical Endocrinology, 2009. In Press. DOI: 10.1111/j.1365-2265.2009.03604.x.

35 Shand BI, Scott RS, Elder PA \& George PM. Plasma adiponectin in overweight, nondiabetic individuals with or without insulin resistance. Diabetes, Obesity \& Metabolism 20035 349-353.

36 Klein S, Fontana L, Young VL, Coggan AR, Kilo C, Patterson BW \& Mohammed BS. Absence of an effect of liposuction on insulin action and risk factors for coronary heart disease. New England Journal of Medicine 2004350 2549-2557.

37 Carrasco F, Ruz M, Rojas P, Csendes A, Rebolledo A, Codoceo J, Inostroza J, Basfi-Fer K, Papapietro K, Rojas J, Pizarro F \& Olivares M. Changes in bone mineral density, body composition and adiponectin levels in morbidly obese patients after bariatric surgery. Obesity Surgery 200919 41-46.

38 Caixas A, Gimenez-Palop O, Gimenez-Perez G, Potau N, Berlanga E, Gonzalez-Glemente JM, Arroyo J, Laferrere B \& Mauricio D. Postprandial adiponectin levels are unlikely to contribute to the pathogenesis of obesity in Prader-Willi syndrome. Hormone Research 200665 39-45.

39 Polak J, Kovacova Z, Holst C, Verdich C, Astrup A, Blaak E, Patel K, Oppert JM, Langin D, Martinez JA, Sorensen TI \& Stich V. Total adiponectin and adiponectin multimeric complexes in relation to weight loss-induced improvements in insulin sensitivity in obese women: the NUGENOB study. European Journal of Endocrinology 2008158 533-541.

40 Butte NF, Comuzzie AG, Cai G, Cole SA, Mehta NR \& Bacino CA. Genetic and environmental factors influencing fasting serum adiponectin in Hispanic children. Journal of Clinical Endocrinology and Metabolism 200590 4170-4176.

41 Nassis GP, Papantakou K, Skenderi K, Triandafillopoulou M, Kavouras SA, Yannakoulia M, Chrousos GP \& Sidossis LS. Aerobic exercise training improves insulin sensitivity without changes in body weight, body fat, adiponectin, and inflammatory markers in overweight and obese girls. Metabolism 200554 1472-1479.

42 Quiros-Tejeira RE, Rivera CA, Ziba TT, Mehta N, Smith CW \& Butte NF. Risk for nonalcoholic fatty liver disease in Hispanic youth with BMI $>$ or $=95$ th percentile. Journal of Pediatric Gastroenterology and Nutrition $2007 \mathbf{4 4} 228-236$.

43 Koebnick C, Roberts CK, Shaibi GQ, Kelly LA, Lane CJ, ToledoCorral CM, Davis JN, Ventura EE, Alexander K, Weigensberg MJ \& Goran MI. Adiponectin and leptin are independently associated with insulin sensitivity, but not with insulin secretion or beta-cell function in overweight Hispanic adolescents. Hormone and Metabolic Research $2008 \mathbf{4 0} 708-712$.

44 Berryman DE, List EO, Coschigano KT, Behar K, Kim JK \& Kopchick JJ. Comparing adiposity profiles in three mouse models with altered GH signaling. Growth Hormone \& IGF Research 2004 14 309-318.

45 Nilsson L, Binart N, Bohlooly YM, Bramnert M, Egecioglu E, Kindblom J, Kelly PA, Kopchick JJ, Ormandy CJ, Ling C \& Billig H. Prolactin and growth hormone regulate adiponectin secretion and receptor expression in adipose tissue. Biochemical and Biophysical Research Communications 2005331 1120-1126. 
46 Andersson B, Carlsson LM, Carlsson B, Albertsson-Wikland K \& Bjarnason R. Decrease in adiponectin levels correlates to growth response in growth hormone-treated children. Hormone Research $200971213-218$.

47 Kanety H, Karasik A, Klinger B, Silbergeld A \& Laron Z. Long-term treatment of Laron type dwarfs with insulin-like growth factor-1 increases serum insulin-like growth factor-binding protein-3 in the absence of growth hormone activity. Acta Endocrinologica 1993128 144-149.

48 Kim HS, Ali O, Shim M, Lee KW, Vuguin P, Muzumdar R, Barzilai N \& Cohen P. Insulin-like growth factor binding protein-3 induces insulin resistance in adipocytes in vitro and in rats in vivo. Pediatric Research 200761 159-164.

49 Halleux CM, Takahashi M, Delporte ML, Detry R, Funahashi T, Matsuzawa Y \& Brichard SM. Secretion of adiponectin and regulation of apM1 gene expression in human visceral adipose tissue. Biochemical and Biophysical Research Communications 2001 288 1102-1107.

50 Kennedy L, Bittel DC, Kibiryeva N, Kalra SP, Torto R \& Butler MG. Circulating adiponectin levels, body composition and obesityrelated variables in Prader-Willi syndrome: comparison with obese subjects. International Journal of Obesity 200630 382-387.

51 Hill DJ, Riley SC, Bassett NS \& Waters MJ. Localization of the growth hormone receptor, identified by immunocytochemistry, in second trimester human fetal tissues and in placenta throughout gestation. Journal of Clinical Endocrinology and Metabolism 199275 646-650.

52 Wang ZV, Schraw TD, Kim JY, Khan T, Rajala MW, Follenzi A \& Scherer PE. Secretion of the adipocyte-specific secretory protein adiponectin critically depends on thiol-mediated protein retention. Molecular and Cellular Biology 200727 3716-3731.

53 Lara-Castro C, Luo N, Wallace P, Klein RL \& Garvey WT. Adiponectin multimeric complexes and the metabolic syndrome trait cluster. Diabetes 200655 249-259.

54 Taksali SE, Caprio S, Dziura J, Dufour S, Cali AM, Goodman TR, Papademetris X, Burgert TS, Pierpont BM, Savoye M, Shaw M, Seyal AA \& Weiss R. High visceral and low abdominal subcutaneous fat stores in the obese adolescent: a determinant of an adverse metabolic phenotype. Diabetes 200857 367-371.
55 Goldstone AP, Thomas EL, Brynes AE, Bell JD, Frost G, Saeed N, Hajnal JV, Howard JK, Holland A \& Bloom SR. Visceral adipose tissue and metabolic complications of obesity are reduced in Prader-Willi syndrome female adults: evidence for novel influences on body fat distribution. Journal of Clinical Endocrinology and Metabolism 200186 4330-4338.

56 Bullo M, Garcia-Lorda P, Peinado-Onsurbe J, Hernandez M, Del Castillo D, Argiles JM \& Salas-Salvado J. TNFalpha expression of subcutaneous adipose tissue in obese and morbid obese females: relationship to adipocyte LPL activity and leptin synthesis. International Journal of Obesity and Related Metabolic Disorders 200226 652-658.

57 Vilarrasa N, Vendrell J, Sanchez-Santos R, Broch M, Megia A, Masdevall C, Gomez N, Soler J, Pujol J, Bettonica C, Aranda H \& Gomez JM. Effect of weight loss induced by gastric bypass on proinflammatory interleukin-18, soluble tumour necrosis factor-alpha receptors, C-reactive protein and adiponectin in morbidly obese patients. Clinical Endocrinology 200767 679-686.

58 del Rincon JP, Iida K, Gaylinn BD, McCurdy CE, Leitner JW, Barbour LA, Kopchick JJ, Friedman JE, Draznin B \& Thorner MO. Growth hormone regulation of p85alpha expression and phosphoinositide 3-kinase activity in adipose tissue: mechanism for growth hormone-mediated insulin resistance. Diabetes 200756 1638-1646.

59 Wolf I, Kuchuck I \& Kanety H. Adiponectin and ghrelin: new players in cancer cachexia and carcinogenesis. Obesity and Metabolism 20062 221-229.

60 Barb D, Williams CJ, Neuwirth AK \& Mantzoros CS. Adiponectin in relation to malignancies: a review of existing basic research and clinical evidence. American Journal of Clinical Nutrition $2007 \mathbf{8 6}$ S858-S866.

61 Shevah O \& Laron Z. Patients with congenital deficiency of IGF-I seem protected from the development of malignancies: a preliminary report. Growth Hormone \& IGF Research 200717 $54-57$.

Received 8 September 2009

Accepted 14 September 2009 